\title{
Effects of groundwater abstraction on two keystone tree species in an arid savanna national park
}

\author{
Eleanor Shadwell ${ }^{1}$, Edmund February ${ }^{\text {Corresp. } 1}$ \\ ${ }^{1}$ Department of Biological Sciences, University of Cape Town, Private Bag, Rondebosch, 7701, Western Cape Province, South Africa \\ Corresponding Author: Edmund February \\ Email address: edmund.february@uct.ac.za
}

\section{Abstract}

Background. In arid systems with no surface water, deep boreholes in ephemeral river beds provide for humans and animals. With continually increasing infrastructure development for tourism in arid wildlife parks such as the Kgalagadi Transfrontier Park in southern Africa we ask what effects increased abstraction may have on large trees. Large trees in arid savannas perform essential ecosystem services by providing food, shade, nesting sites and increased nutrients for many other plant and animal species and for this are regarded as keystone species.

Methods. We determine seasonal fluctuations in the water table while also determining the water source for the dominant large tree species in the Auob and Nossob rivers in the Park. We also determine the extent to which these trees are physiologically stressed using leaf $\delta^{13} \mathrm{C}$, xylem pressure potentials, specific leaf area and an estimate of canopy death. We do this both upstream and downstream of a low water use borehole in the Auob River and a high water use borehole in the Nossob River.

Results. Our results show that the trees are indeed using deep groundwater in the wet season and that this is the same water used by people. In the dry season, trees in the Auob downstream of the active borehole become detached from the aquifer and use more isotopically enriched soil water. In the Nossob in the dry season, all trees use isotopically enriched soil water, and downstream of the active borehole use stomatal regulation to maintain leaf water potentials. These results suggest that trees in the more heavily utilised Nossob are under more water stress than those trees in the Auob but that trees in both rivers demonstrate physiological adaptation to the changes in available water with smaller heavier leaves, no significant canopy dieback and in the dry season in the Nossob stomatal regulation of leaf water potentials.

Discussion. An increase in abstraction of groundwater particularly at the Nossob borehole may cause an additional draw down of the water table adding to the physiological stress demonstrated in our study. The managers of the Kgalagadi Transfrontier Park have a mandate that includes biodiversity conservation. To fulfil this mandate, upper and lower thresholds for groundwater abstraction that allow for an adequate ecological reserve have to be determined. 


\section{Effects of groundwater abstraction on two keystone tree species in}

\section{2 an arid savanna national park.}

3

4 E. Shadwell.

5 E. February*. Edmund.February@uct.ac.za

6

7 Department of Biological Sciences, University of Cape Town, Private Bag, Rondebosch, 7701.

8

$9 *$ Corresponding author 


\section{Abstract}

12 Background. In arid systems with no surface water, deep boreholes in ephemeral river beds provide for humans and animals. With continually increasing infrastructure development for tourism in arid wildlife parks such as the Kgalagadi Transfrontier Park in southern Africa we ask what effects increased abstraction may have on large trees. Large trees in arid savannas perform essential ecosystem services by providing food, shade, nesting sites and increased species.

Methods. We determine seasonal fluctuations in the water table while also determining the water source for the dominant large tree species in the Auob and Nossob rivers in the Park. We also determine the extent to which these trees are physiologically stressed using leaf $\delta^{13} \mathrm{C}$, xylem pressure potentials, specific leaf area and an estimate of canopy death. We do this both upstream and downstream of a low water use borehole in the Auob River and a high water use borehole in the Nossob River.

Results. Our results show that the trees are indeed using deep groundwater in the wet season and that this is the same water used by people. In the dry season, trees in the Auob downstream of the active borehole become detached from the aquifer and use more isotopically enriched soil water. In the Nossob in the dry season, all trees use isotopically enriched soil water, and downstream of the active borehole use stomatal regulation to maintain leaf water potentials. These results suggest that trees in the more heavily utilised Nossob are under more water stress than those trees in the Auob but that trees in both rivers demonstrate physiological adaptation to the changes in available water with smaller heavier leaves, no significant canopy dieback and in the dry season in the Nossob stomatal regulation of leaf water potentials.

Discussion. An increase in abstraction of groundwater particularly at the Nossob borehole may cause an additional draw down of the water table adding to the physiological stress demonstrated in our study. The managers of the Kgalagadi Transfrontier Park have a mandate that includes biodiversity conservation. To fulfil this mandate, upper and lower thresholds for groundwater abstraction that allow for an adequate ecological reserve have to be determined. 


\section{Introduction}

43 All of the perennial rivers in the Kruger National Park in South Africa have been

44 anthropogenically modified by water abstraction and increased sediment and pollution loads ( $\mathrm{Du}$

45 Preez \& Steyn 1992; Rogers \& Biggs 1999). It has also been demonstrated that ephemeral rivers

46 such as the Auob and the Nossob in the more arid Kgalagadi Transfrontier Park are currently not

47 threatened by water abstraction even though the first boreholes were sunk in these rivers in the

48 1930's (Mills \& Retief 1984; Nel et al. 2007; Van Wyk \& le Riche 1984). Tourism development

49 is seen as fundamental to community development and poverty alleviation in many parts of the

50 world and is therefore heavily promoted in many National Parks (Binns \& Nel 2002; Neto 2003).

51 To this end there have been substantial increases in tourist infrastructure at Nossob,

52 Kieliekrankie and Urikaruus tourist camps in the Kgalagadi Transfrontier Park (SANParks 2016)

53 (Fig. 1). As there is no natural surface water in this park, all the water for this increase in tourism 54 development has to come from groundwater abstraction (Mills \& Retief 1984; Van Wyk \& le 55 Riche 1984). The economic benefits of tourism have been illustrated in several publications, while the environmental impacts resulting from groundwater abstraction for this have also been demonstrated (Hall 2001; Mbaiwa 2003; Stromberg 1993). Studies have shown that an increase in infrastructure development in arid environments can result in both short and long term water table declines with negative repercussions on groundwater dependant ecosystems (Barron et al. 2014; Groom et al. 2000; Lite \& Stromberg 2005). The effects of such abstraction on vegetation structure in arid systems with no surface water have however not been demonstrated.

62 Arid savanna such as at our study site in the Kgalagadi Transfrontier Park occur across the world, 63 from the Caatinga in northeast Brazil, through to the Mulga of central Australia (Huntley \& Walker 64 2012; Nix \& Austin 1973). In arid savanna trees are scattered in an expansive bare ground, shrub, and grass matrix. At our study site Acacia erioloba and Acacia haematoxylon dominate in the dry river beds as the only large tree species, along with scattered smaller trees and bushes with dwarf

67 shrubs and grasses occurring in sparse clumps (Leistner 1959; Van Rooyen et al. 2008). Both $A$.

68 erioloba and A. haematoxylon provide nesting sites, shade, food resources and soil nutrients for a variety of other plants and animals and because of this are considered as keystone species (Dean et al. 1999; Milton \& Dean 1995). 
71 Recent research has demonstrated that trees growing in the Kuruman River a system similar to 72 the Auob and the Nossob are using deep (56 m) water (Schachtschneider \& February 2013). If 73 these trees are indeed reliant on deep water and this is the same water that is being pumped for tourism development then there is an urgent need to develop a conceptual understanding of groundwater recharge processes and the interaction between groundwater and the trees growing in the river bed. Several studies have now demonstrated that it is possible to determine the water source of a plant through an analysis of the stable hydrogen and oxygen isotope ratios of the water in the xylem tissue of that plant (Dawson \& Ehleringer 1991; Ehleringer \& Dawson 1992; February et al. 2007a). The method is based on the assumption that the water in the xylem of non-photosynthesising tissue will have the same stable isotope ratio as the water source (Dawson \& Ehleringer 1991). We determine the interaction between groundwater and the two tree species A. erioloba and A. haematoxylon growing in the dry beds of the ephemeral Auob and Nossob rivers in the Kgalagadi Transfrontier Park (Fig. 1). We do this by firstly determining the water source for the two species using hydrogen and oxygen isotope ratios of both xylem and borehole water (Schachtschneider \& February 2013). We then determine the extent to which the trees are physiologically stressed using stable carbon isotope ratios of the leaves, midday xylem pressure potentials, specific leaf area and an estimate of canopy death (Farquhar et al. 1989; Liu \& Stützel 2004; Scholander et al. 1965).

National Parks in South Africa have adopted strategic adaptive management with clear ecosystem management goals. The achievement of these goals is evaluated by using environmental indicators (Biggs \& Rogers 2003). With a constant demand for resources in the Kgalagadi Transfrontier Park there is a real need to ascertain what the natural balance of groundwater is and what the interaction is between this water and the trees growing in the dry river beds. Such an understanding is critical for determining the influence of water table flux on riparian species thereby allowing park management to develop a sustainable water resource allocation that meets the needs of both tourism and the environment (Chen et al. 2016).

\section{Methods}

\section{Study site}

The study site is located in the western and southern part of the Kgalagadi Transfrontier Park, in southern Africa. We sampled at four boreholes in the Park, Urikaruus waterhole and Kamqua 
101 waterhole upstream and downstream respectively of the Urikaruus Wilderness camp borehole (-

$10226.010832^{\circ}, 20.349627^{\circ}$ ) in the Auob River; and North Kwang and Qubit'je Quap boreholes

103 upstream and downstream respectively of the Nossob camp borehole $\left(-25.287383^{\circ}, 20.537513^{\circ}\right)$

104 in the Nossob River (Fig. 1).

105 The climate for the region is characterised by distinctly seasonal rainfall with a hot wet season

106 from late November to early April. Mean annual rainfall (1984 to 2014) increases from $180 \mathrm{~mm}$

107 at Nossob $\left(-25.4212^{\circ}, 20.5968^{\circ}\right)$ in the north to $220 \mathrm{~mm}$ at Twee Rivieren $116 \mathrm{~km}$ to the south (-

$10826.4721^{\circ}, 20.6116^{\circ}$ ). Mean annual maximum and minimum temperatures at Twee Rivieren are

$10936.7^{\circ} \mathrm{C}$ and $0.1^{\circ} \mathrm{C}$ for January and July respectively (South African Weather Bureau).

110 The general landscape is primarily covered in aeolian dune sand underlain by silcretes and

111 calcretes of the Cenozoic Kalahari Group. Our sampling sites in the riverbed, however, typically

112 consist of fine grained silts (Mucina \& Rutherford 2006). In the Auob, A. erioloba and $A$.

113 haematoxylon (biogeographically endemic to the Kalahari) are the dominant tree species, with

114 Acacia mellifera and Rhigozum trichotomum common shrubs. Grasses such as the annual

115 Schmidtia kalahariensis and perennial Stipagrostis obtusa occur in sparse clumps (Leistner

116 1959; Mucina \& Rutherford 2006). The vegetation in the Nossob is very similar to that of the

117 Auob, but without $A$. haematoxylon, only large $A$. erioloba trees. Common grasses here are the

118 perennial Panicum coloratum var. coloratum and Eragrostis bicolor (Bothma \& De Graaff 1973;

119 Mucina \& Rutherford 2006).

\section{Water Source}

\section{Borehole water level}

122 To monitor fluxes in water table through time piezometers (Solinst-Leverlogger, Georgetown,

123 Ontorio, Canada) were inserted into our sampled boreholes, North Kwang and Qubit'je Quap in

124 the Nossob and Urikaruus and Kamqua in the Auob from the $25^{\text {th }}$ August 2012 to the $31^{\text {st }}$

125 January 2014 (Fig. 1).

\section{Oxygen and hydrogen stable isotopes}

127 We use the hydrogen and oxygen stable isotope ratios of water extracted from non-

128 photosynthesising xylem tissue to determine the water source for both $A$. erioloba and $A$.

129 haematoxylon (February et al. 2007a; Schachtschneider \& February 2013). The method is based 
130 on the assumption that water extracted from non-photosynthesising xylem tissue of a tree will

131 have the same isotopic ratio as the source water for that tree (White et al. 1985). For this we

132 collected two twig samples $(\sim 0.5 \mathrm{~cm} \mathrm{X} 6 \mathrm{~cm})$ from six A. erioloba and six A. haematoxylon

133 (twelve trees) upstream and six trees for each species (twelve trees) downstream of the active

134 borehole for the Urikaruus Wilderness Camp (Fig. 1). At the same time we also collected two

135 twig samples from eight $A$. erioloba trees upstream and eight trees downstream of the active

136 borehole for the Nossob camp (Fig. 1). These samples were collected into borosilicate tubes

137 (Kimax-Kimble, New Jersey, USA) which were placed directly onto a cryogenic vacuum

138 extraction line to separate out the water for stable isotope analysis (Schachtschneider \& February

139 2013). We did this on three occasions, in January 2013 (wet season), July 2013 (dry season) and

140 January 2014 (wet season).

141 We also collected water from each of our four boreholes at Urikaruus, Kamqua, North Kwang

142 and Qubit'je Quap in August 2012 (dry season), November 2012 and January 2013 (wet season)

143 July and August 2013 (dry season) and January 2014 (wet season). Rain water samples were

144 collected opportunistically at Twee Rivieren, North Kwang and Nossob. All water samples were

145 stored in $20 \mathrm{ml}$ glass screw top bottles (Wheaton Liqid Scintillation Vials, Millville, NJ, USA)

146 before analyses for both ${ }^{2} \mathrm{H} / \mathrm{H}$ and ${ }^{18} \mathrm{O} /{ }^{16} \mathrm{O}$ using a Thermo Delta Plus XP Mass Spectrometer

147 (Hamburg Germany) at the University of Cape Town. The same mass spectrometer was used to

148 determine ${ }^{13} \mathrm{C} /{ }^{12} \mathrm{C}$ ratios of the leaves from our study trees.

\section{Plant Moisture Stress}

\section{Leaf stable carbon isotope ratios}

151 We use the stable carbon isotope ratios of leaves to determine the efficiency of carbon

152 assimilation and plant water use (intrinsic water use efficiency) for our study trees (Dawson et al.

153 2002; Farquhar et al. 1989). Plants regulate the amount of water lost to the atmosphere by

154 closing or opening stomata. As stomata close with a decrease in available water there is less

155 carbon assimilated and less discrimination against the heavier ${ }^{13} \mathrm{C}$ isotope resulting in more

156 positive leaf $\delta^{13} \mathrm{C}$ values (Farquhar et al. 1989). In the middle of the wet season in January 2013

157 we collected ten fully mature whole leaves from each of our study trees in both the Auob (twenty

158 four trees) and the Nossob (sixteen trees) rivers. Prior to mass spectrometry the leaves were oven 
159 dried at $70^{\circ} \mathrm{C}$ to constant weight before being ground to a fine powder using a Retsch MM200

160 ball mill (Retsch, Haan, Germany).

\section{Xylem pressure potentials}

162 Xylem pressure potentials (XPP's) are a relative indicator of the amount of water available to the 163 plant through a determination of the amount of tension the water column is under (Hempson et 164 al. 2007; Scholander et al. 1965). We determined midday XPP's in both the wet and dry season 165 of 2013 using a Scholander-type pressure chamber (PMS Instrument Company, Corvallis, OR, 166 USA). We specifically used midday rather than predawn XPP's because of the hazards related to 167 working in the dark with large carnivores present in the area (Hempson et al. 2007). We also 168 assumed that midday readings in the middle of both the wet and dry seasons should sufficiently 169 illustrate any differences in plant available water between trees at our study site.

\section{Specific leaf area}

171 Specific leaf area (the ratio of leaf area to leaf dry mass) declines with decreasing soil moisture 172 as leaves become smaller and heavier to reduce water loss and susceptibility to desiccation 173 (Ackerly et al. 2002; Liu \& Stützel 2004). We collected ten fully mature whole leaves from each 174 of our trees in both the wet and the dry season of 2013. The entire leaf including both petiole and 175 rachis were then photographed against a white background before determining leaf area using the 176 open source software ImageJ (Abràmoff et al. 2004).

\section{Canopy dieback}

178 Using two photographs for each tree we determined the amount of canopy dieback on all of our 179 study trees. Semi-deciduous species such as A. erioloba and A. haematoxylon are rarely leafless 180 in the dry season due to synchronised leaf fall and new leaf emergence (Sekhwela \& Yates 181 2007). Twigs and branches with no leaves were therefore attributed to heavy browse or drought 182 induced leaf mortality. We photographed the canopy of each of our study trees in both the wet 183 and the dry season of 2013. Each photograph was taken through an 18-200 mm f/3.5 - $6.3 \mathrm{HSM}$ 184 DC lens (Sigma, Fukushima, Japan) with PRO1 D UV (W) filter attached, (Kenko, Tokyo, 185 Japan) fixed at $52 \mathrm{~mm}$, F8 aperture using a Nikon D60 camera (Nikon, Ayuthaya, Thailand) set 186 on a tripod (290 Series; Manfrotto, Cassola, Italy) $1.5 \mathrm{~m}$ off the ground. The distance between 187 camera and tree was measured from the mid-point of the tripod to the base of the tree. 
188 Photographs were taken between $10 \mathrm{~h} 00$ and $16 \mathrm{~h} 00$ in two directions, east to west and north to 189 south, unless obstructed when the direction was switched through $180^{\circ}$. The angle of the tripod

190 head was adjusted using the spirit level set into the tripod, so that the camera was always

191 horizontal (relative to the ground) and tilted vertically keeping the entire tree canopy just inside

192 the field of view. For the calibration of each photograph, a retractable $5 \mathrm{~m}$ aluminium ranging

193 rod (levelling staff; Leica Geosystems, St. Gallen, Switzerland) was held vertically at the edge of

194 the canopy in the field of view (Sup. Fig. 1).

195 Each photograph was overlaid by a grid (50 $\mathrm{cm}$ boxes, subdivided by 10$)$, using Adobe

196 Photoshop (CS5 v12.0 x 32C Adobe Systems Software Ltd, Ireland), with living (leaf) and dead

197 material (twigs $<5 \mathrm{~cm}$ thick) noted at each grid intercept around the outer $15 \mathrm{~cm}$ edge of the

198 canopy (Sup Fig. 1). From the total number of intercepts (dead + live), the percentage of canopy

199 dieback was calculated for each of the two photographs and the result averaged per tree.

\section{Statistics}

201 The data were split into three sets according to river and species: A. haematoxylon and $A$.

202 erioloba in the Auob; and A. erioloba in the Nossob.

203 The differences between upstream and downstream for six dependent variables were assessed:

204 Wilcoxon Sum Rank tests for leaf $\delta^{13} \mathrm{C}$ values, linear mixed effects models for $\delta^{18} \mathrm{O}$ and $\delta^{2} \mathrm{H}$

205 values and midday xylem pressure potentials, linear models for specific leaf area and Kruskal-

206 Wallis Rank Sum tests followed by a Pairwise Wilcoxon with Bonferroni correction for canopy

207 dieback. The models were developed using 'season' (wet/dry), 'position' (upstream/downstream)

208 and the interaction between these with individual trees as the random effect (the same trees were

209 sampled in both seasons). All tests on the data were assessed in R@ v3.1.2 (R Core Development

210 Team 2014) and a value of $\mathrm{p}<0.05$ required for significance.

\section{Results}

\section{Water Source}

\section{Borehole water level}

214 Instrument malfunction for our piezometers affected recordings, so that only those readings of

215 which we are certain were considered (Sup. Fig 2). Water level depth varied between $38 \mathrm{~m}$ to 46 
$216 \mathrm{~m}$ in the Auob and $49 \mathrm{~m}$ to $59 \mathrm{~m}$ in the Nossob. In both the Auob and Nossob, the water table at

217 the upstream borehole was lower than that of the downstream borehole. This was unexpected,

218 but we speculate that this is as a result of a calcrete layer close to the surface underlying the

219 aquifer for the downstream boreholes in both rivers. Both the Auob boreholes show a similar

220 pattern in groundwater flux through time with a steady drop in water level of $\pm 4 \mathrm{~m}$ soon after

221 the peak of the dry season (July/August), and a subsequent rise of $\pm 4 \mathrm{~m}$ matching the peak of the

222 wet season rains (January/February). The Nossob downstream water level showed a $6 \mathrm{~m}$ drop

223 two months after the peak of the dry season, but only a $2 \mathrm{~m}$ rise during the peak of the following

224 wet season with an unusually low asymptote from the middle of the wet season that may be the

225 result of instrument malfunction (Sup. Fig. 2).

\section{Oxygen and hydrogen stable isotopes}

227 Meteoric waters worldwide follow a Rayleigh distillation process that results in a linear

228 relationship between $\delta^{18} \mathrm{O}$ and $\delta^{2} \mathrm{H}$, termed the global meteoric water line (GMWL; $\mathrm{y}=8 \mathrm{x}+10$ )

229 (Craig, 1961; Gat, 1996). For plant water source studies in arid environments these linear

230 relationships (essentially representing evaporation) are extremely useful as deep (non-

231 evaporatively enriched) and shallower moisture sources (evaporatively enriched) can be readily

232 distinguished, with deep water plotting more negative values and shallow water more positive

233 values (February et al. 2007b; West et al. 2012). We constructed our own local meteoric water

234 line (LMWL; $y=5.06 \mathrm{x}$ - 6.75) from rain water samples collected at Twee Rivieren in January

235 and August and between North Kwang and Nossob in August 2013 (Fig. 2). Rainfall at our study

236 site is extremely seasonal and even after no rainfall for several months and with mean midday

237 temperatures between $30^{\circ} \mathrm{C}$ and $40^{\circ} \mathrm{C}$ our study trees were not deciduous with $\delta^{18} \mathrm{O}$ and $\delta^{2} \mathrm{H}$

238 values indistinguishable from that of groundwater (Fig. 2).

239 The results for all xylem water samples for both A. erioloba and A. haematoxylon in the Auob

240 River plotted below the LMWL with wet season values similar to that of groundwater (Fig. 2). In

241 the dry season however, downstream of the abstraction point, xylem water $\delta^{18} \mathrm{O}$ values for both

242 species are significantly different from groundwater $\delta^{18} \mathrm{O}$ values (Fig 2). In the Nossob, $\delta^{18} \mathrm{O}$

243 values are similar to that of the Auob in the wet season in that xylem water $\delta^{18} \mathrm{O}$ values are

244 indistinguishable from that of the groundwater (Fig 2). Conversely, in the dry season, $\delta^{18} \mathrm{O}$

245 values for xylem water in trees both upstream and downstream of the abstraction borehole are 
246 significantly different from groundwater values. The downstream values are however more 247 positive than the upstream values.

248 Plant Moisture Stress

\section{Leaf stable carbon isotope ratios}

250 In the Auob, there were no significant differences in leaf $\delta^{13} \mathrm{C}$ values for either upstream or

251 downstream A. haematoxylon or A. erioloba (Fig. 3). In the Nossob however, A. erioloba values

252 downstream $(-24.7 \pm 0.4 \%)$ were significantly more enriched $(\mathrm{W}=52, \mathrm{p}=0.04)$ relative to

253 upstream $\delta^{13} \mathrm{C}$ values $(-26.3 \pm 0.37 \%)$.

254 Xylem Pressure Potentials

255 In the Auob, there were no significant differences in midday xylem pressure potentials (XPP) for

256 either upstream or downstream trees (Fig 4). In the Nossob the downstream trees in the dry

257 season (average -3.1 MPa) had significantly more positive XPP's than upstream trees regardless

258 of season (average -3.5 and $-3.4 \mathrm{MPa}$ respectively).

259 Specific Leaf Area

260 In the Auob River, both tree species downstream of the active borehole had significantly lower

261 SLA values in the dry season than in the wet season. For the Nossob River, SLA values were

262 overall significantly lower in the dry season than in the wet season, but there was no significant

263 difference between upstream and downstream. (Fig 5).

\section{Canopy dieback}

265 There were no significant seasonal differences in average percentage canopy dieback for $A$.

266 haematoxylon in the Auob and A. erioloba in the Nossob (Fig. 6). In the Auob, A. erioloba

267 showed significantly more dieback downstream in both seasons. Average canopy dieback was

268 higher in A. haematoxylon (between 26-30\%) than in A. erioloba (between $12-20 \%$ ).

\section{Discussion}

270 The depth to the aquifer in the two rivers at our study site varies between $38 \mathrm{~m}$ and $59 \mathrm{~m}$ with

271 our water isotope analysis demonstrating that the trees in these rivers are using this deep water.

272 While ours is the first study to demonstrate the use of deep groundwater for A. haematoxylon 
273 these results are in agreement with research $120 \mathrm{~km}$ south east of our study site in the Kuruman

274 River showing this for A. erioloba (Schachtschneider \& February 2013). Our results also show

275 that there are differences between the low water use site in the Auob and the high water use site

276 in the Nossob. In the Auob both of our study species use deep ground water in the wet season. In

277 the dry season however these trees use deep groundwater upstream of the borehole and in losing

278 contact with the groundwater use more isotopically enriched soil water downstream.

279 Significantly lower specific leaf area values for both species downstream indicate that in the dry 280 season these downstream trees have physiologically adapted to the change in available water by 281 producing smaller heavier leaves with marginally but not significantly more negative XPP's.

282 As in the Auob, A.erioloba in the Nossob use deep ground water in the wet season. In the dry 283 season, however, all trees, both upstream and downstream, use more isotopically enriched soil 284 water and have smaller heavier leaves. Significantly more positive $\delta^{13} \mathrm{C}$ values for downstream 285 trees suggest that these trees are maintaining leaf water potential through stomatal closure, a 286 conclusion verified by more positive XPP's (McDowell et al. 2008). These results demonstrate 287 that trees in the Nossob adjust to lower levels of water availability by closing stomata to maintain 288 relatively high water potentials thereby preventing loss of or damage to xylem conducting tissue 289 as is indicated in the low percentages of canopy dieback (Jones \& Sutherland 1991; West et al. 290 2012). With only a change in SLA but no change in XPP's or leaf $\delta^{13} \mathrm{C}$ values and little canopy 291 dieback A.erioloba in the Auob do not demonstrate the same levels of stress to changes in 292 available water.

293 At our study site in the Nossob near a borehole with a higher extraction rate than at our study site 294 in the Auob the A. erioloba trees demonstrate physiological adaption to a flux in the water table 295 of between $4.5 \mathrm{~m}$ and $5.2 \mathrm{~m}$ between the wet and the dry season. This flux in water table depth is 296 similar to the $5 \mathrm{~m}$ flux attributed to water abstraction in the north-western sector of South Africa 297 (van Dyk et al. 2008). In the Sonoran desert of the American South West, groundwater declines 298 of 18 - $30 \mathrm{~m}$ have resulted in low stem water potentials, reduced leaf size and high levels of 299 canopy mortality in Prosopis velutina (Stromberg 1993). Similarly in the Murray Darling Basin 300 of SE Victoria in Australia declines in water level of between 12.1 and $22.6 \mathrm{~m}$ for Eucalyptus 301 camaldulensis and 12.6 and $26.7 \mathrm{~m}$ for Eucalyptus populnea resulted in significantly poorer 
302 canopy condition (Kath et al. 2014). Our trees in the Nossob are exhibiting similar responses

303 with a much smaller fluctuation in the water table.

304 Trees in the Kalahari are the deepest rooted trees in the world and our results show that the

305 reason for these deep roots is to source water at depths of between 40 and $60 \mathrm{~m}$ (Canadell et al.

306 1996). While the Nossob trees may be physiologically tolerant of $4-5 \mathrm{~m}$ fluctuations in water

307 table this could change with drought such as the current 2015-2016 one.

\section{Conclusion}

309 The higher abstraction for the Nossob camp has resulted in the trees near that camp showing

310 signs that groundwater depths in the dry season have exceeded thresholds identified by studies in

311 Australia and America as being critical (Kath et al. 2014; Stromberg 1993). The decline in water

312 table in the Kalahari is not as much as that in Australia and America but the water column in the

313 Kalahari trees is under greater negative pressure because of the distance to the water table of 40

$314-60 \mathrm{~m}$ as opposed to $5 \mathrm{~m}$ in the American SW (Koch et al. 2004; Ryan \& Yoder 1997). The

315 increase in dry season tension on the water column resulting from a decline in the water table has

316 resulted in the Nossob trees controlling for water loss through stomatal regulation. In the event of

317 a drought however such stomatal regulation can result in carbon starvation, canopy dieback and

318 canopy death (McDowell et al. 2008; West et al. 2012). Our perception is that there are many

319 more dead trees in the Nossob than there are in the Auob. We did not evaluate this but we

320 speculate that these deaths were the result of some past drought event.

321 National Parks not only in South Africa but throughout the world are under pressure to increase

322 revenue. This growing demand for ecotourism will increase pressure on groundwater resources

323 in arid systems where there are no alternative water sources. Aquifer management may be

324 described as the art of abstracting no more water than is replenished. Such abstraction should

325 take into consideration the ecological reserve set out in the National Water Act (RSA 1998) that

326 allows for an adequate and timeous supply of water to maintain the integrity of not only the

327 rivers but also the terrestrial plants reliant on the aquifer (Baron et al. 2002). There has been no

328 published research on abstraction or replenishment rates for any of the aquifers supplying the rest

329 camps in the Park. Our results would suggest very strongly that this should be a research focus

330 for the future and that the Park should develop a strategic adaptive management approach for

331 groundwater use. Such an approach would develop thresholds for potential concern (Biggs and 
332 Rogers 2003) that would allow for an adequate ecological reserve as our study suggests that trees

333 in the Park, and in particular the Nossob, are nearing and have possibly exceeded the threshold of

334 physiological tolerance.

\section{Acknowledgments}

336 We would like to thank South African National Parks for allowing us to do the research in the

337 Kgalagadi Transfrontier Park. We are grateful to Graeme Ellis, Paola Vimercati and Amy

338 Betzelberger for help with the fieldwork.

339 Author Contributions

340 Both authors contributed equally to this manuscript and both authors approved of the final

341 manuscript for submission.

\section{Data Accessibility}

343 Our data are available at the South African National Park Data Repository

344 http://dataknp.sanparks.org/sanparks/metacat/judithk.111141.4/sanparks

\section{References}

346

347

348

349

350

351

352

353

354

355

356

357

358

359

360

361

362

363

364

365

Abràmoff M.D., Magalhães P.J. \& Ram S.J. 2004. Image processing with ImageJ. Biophotonics international 11: 36-42.

Ackerly D., Knight C., Weiss S., Barton K. \& Starmer K. 2002. Leaf size, specific leaf area and microhabitat distribution of chaparral woody plants: contrasting patterns in species level and community level analyses. Oecologia 130: 449-457.

Baron J.S., Poff N.L., Angermeier P.L., Dahm C.N., Gleick P.H., Hairston Jr N.G., Jackson R.B., Johnston C.A., Richter B.D. \& Steinman A.D. 2002. Meeting ecological and societal needs for freshwater. Ecological Applications 12: 1247-1260.

Barron O., Froend R., Hodgson G., Ali R., Dawes W., Davies P. \& McFarlane D. 2014. Projected risks to groundwater-dependent terrestrial vegetation caused by changing climate and groundwater abstraction in the Central Perth Basin, Western Australia. Hydrological Processes 28: 5513-5529.

Biggs H.C. \& Rogers K.H. 2003. An adaptive system to link science, monitoring and management in practice. in Biggs H. C., Rogers K. H. \& Du Toit J. (eds.), The Kruger experience. Ecology and management of savanna heterogeneity. Island Press, Washington, pp. 59-80.

Binns T. \& Nel E. 2002. Tourism as a local development strategy in South Africa. The geographical journal 168: $235-247$.

Bothma J.D.P. \& De Graaff G. 1973. A habitat map of the Kalahari Gemsbok National Park. Koedoe 16: 181-188.

Canadell J., Jackson R., Ehleringer J., Mooney H., Sala O. \& Schulze E.-D. 1996. Maximum rooting depth of vegetation types at the global scale. Oecologia 108: 583-595. 
366

367

368

369

370

371

372

373

374

375

376

377

378

379

380

381

382

383

384

385

386

387

388

389

390

391

392

393

394

395

396

397

398

399

400

401

402

403

404

405

406

407

408

409

410

411

412

Chen Y., Chen Y., Xu C. \& Li W. 2016. The effects of groundwater depth on water uptake of Populus euphratica and Tamarix ramosissima in the hyperarid region of Northwestern China. Environmental Science and Pollution Research: 1-9.

Dawson T.E. \& Ehleringer J.R. 1991. Streamside trees that do not use stream water. Nature 350: 335337.

Dawson T.E., Mambelli S., Plamboeck A.H., Templer P.H. \& Tu K.P. 2002. Stable isotopes in plant ecology. Annual Review of Ecology and Systematics: 507-559.

Dean W., Milton S. \& Jeltsch F. 1999. Large trees, fertile islands, and birds in arid savanna. Journal of Arid Environments 41: 61-78.

Du Preez H. \& Steyn G. 1992. A preliminary investigation of the concentration of selected metals in the tissues and organs of the tigerfish (Hydrocynus vittatus) from the Olifants River, Kruger National Park, South Africa. Water S. A. 18: 131-136.

Ehleringer J. \& Dawson T. 1992. Water uptake by plants: perspectives from stable isotope composition. Plant, Cell \& Environment 15: 1073-1082.

Farquhar G., Hubick K., Condon A. \& Richards R. 1989. Carbon isotope fractionation and plant water-use efficiency. Stable isotopes in ecological research. Springer, pp. 21-40.

February E.C., Higgins S.I., Newton R. \& West A.G. 2007a. Tree distribution on a steep environmental gradient in an arid savanna. Journal of Biogeography 34: 270-278.

February E.C., West A.G. \& Newton R.J. 2007b. The relationship between rainfall, water source and growth for an endangered tree. Austral Ecology 32: 397-402.

Groom P.K., Froend R.H. \& Mattiske E.M. 2000. Impact of groundwater abstraction on a Banksia woodland, Swan Coastal Plain, Western Australia. Ecological Management \& Restoration 1: 117124.

Hall C.M. 2001. Trends in ocean and coastal tourism: the end of the last frontier? Ocean \& Coastal Management 44: 601-618.

Hempson G.P., February E.C. \& Verboom G.A. 2007. Determinants of savanna vegetation structure: Insights from Colophospermum mopane. Austral Ecology 32: 429-435.

Huntley B.J. \& Walker B.H. 2012. Ecology of tropical savannas. Springer Science \& Business Media.

Jones H. \& Sutherland R. 1991. Stomatal control of xylem embolism. Plant, Cell \& Environment 14: 607612.

Kath J., Reardon-Smith K., Le Brocque A., Dyer F., Dafny E., Fritz L. \& Batterham M. 2014. Groundwater decline and tree change in floodplain landscapes: identifying non-linear threshold responses in canopy condition. Global Ecology and Conservation 2: 148-160.

Koch G.W., Sillett S.C., Jennings G.M. \& Davis S.D. 2004. The limits to tree height. Nature 428: 851-854.

Leistner O. 1959. Notes on the vegetation of the Kalahari Gemsbok National Park with special reference to its influence on the distribution of antelopes. Koedoe 2: 128-151.

Lite S.J. \& Stromberg J.C. 2005. Surface water and ground-water thresholds for maintaining PopulusSalix forests, San Pedro River, Arizona. Biological Conservation 125: 153-167.

Liu F. \& Stützel H. 2004. Biomass partitioning, specific leaf area, and water use efficiency of vegetable amaranth (Amaranthus spp.) in response to drought stress. Scientia horticulturae 102: 15-27.

Mbaiwa J.E. 2003. The socio-economic and environmental impacts of tourism development on the Okavango Delta, north-western Botswana. Journal of Arid Environments 54: 447-467.

McDowell N., Pockman W.T., Allen C.D., Breshears D.D., Cobb N., Kolb T., Plaut J., Sperry J., West A. \& Williams D.G. 2008. Mechanisms of plant survival and mortality during drought: why do some plants survive while others succumb to drought? New Phytologist 178: 719-739.

Mills M. \& Retief P. 1984. The response of ungulates to rainfall along the riverbeds of the southern Kalahari. Koedoe 27: 129-141. 
413 Milton S. \& Dean W. 1995. How useful is the keystone species concept, and can it be applied to Acacia

414

415

416

417

418

419

420

421

422

423

424

425

426

427

428

429

430

431

432

433

434

435

436

437

438

439

440

441

442

443

444

445

446

447 erioloba in the Kalahari Desert? Zeitschrift fuer Oekologie und Naturschutz (Germany).

Mucina L. \& Rutherford M. 2006. The vegetation of South Africa, Lesoto and Swaziland. Strelitzia 19. South African National Biodiversity Institute, Pretoria. Memoirs of the Botanical Survey of South Africa.

Nel J.L., Roux D.J., Maree G., Kleynhans C.J., Moolman J., Reyers B., Rouget M. \& Cowling R.M. 2007. Rivers in peril inside and outside protected areas: a systematic approach to conservation assessment of river ecosystems. Diversity and Distributions 13: 341-352.

Neto F. 2003. A new approach to sustainable tourism development: Moving beyond environmental protection. Natural resources forum. Wiley Online Library, pp. 212-222.

Nix H. \& Austin M. 1973. Mulga: a bioclimatic analysis. Tropical Grasslands 7: 9-21.

Rogers K. \& Biggs H. 1999. Integrating indicators, endpoints and value systems in strategic management of the rivers of the Kruger National Park. Freshwater Biology 41: 439-451.

RSA. 1998. Republic of South Africa. National Water Act. Government Printer, Cape Town.

Ryan M.G. \& Yoder B.J. 1997. Hydraulic limits to tree height and tree growth. Bioscience 47: 235-242.

SANParks. 2016. Kgalagadi Transfrontier Park. 2004-2016. . http://www.sanparks.org/parks/kgalagadi/all.php [2016, Jan 20].

Schachtschneider K. \& February E.C. 2013. Impact of Prosopis invasion on a keystone tree species in the Kalahari Desert. Plant Ecology 214: 597-605.

Scholander P.F., Hammel H., Bradstreet E.D. \& Hemmingsen E. 1965. Sap pressure in vascular plants. science 148: 339-346.

Sekhwela M. \& Yates D. 2007. A phenological study of dominant acacia tree species in areas with different rainfall regimes in the Kalahari of Botswana. Journal of Arid Environments 70: 1-17.

Stromberg J. 1993. Riparian mesquite forests: a review of their ecology, threats, and recovery potential. Journal of the Arizona-Nevada Academy of Science: 111-124.

van Dyk G.S., Makhetha J., Potgieter D., Zikali T., Leeme V., Moletsane F. \& Vonya T. 2008. Groundwater Resources in the Northern Cape Province 2008 (combined). Groundwater status poster. Department Water Affairs and Forestry, Kimberley, South Africa.

Van Rooyen M.W., Van Rooyen N., Bothma J.d.P. \& Van den Berg H.M. 2008. Landscapes in the Kalahari Gemsbok National Park, South Africa. Koedoe 50: 99-112.

Van Wyk P. \& le Riche E. 1984. The Kalahari Gemsbok National Park: 1931-1981. Koedoe 27: 21-31.

West A.G., Dawson T.E., February E., Midgley G.F., Bond W. \& Aston T.L. 2012. Diverse functional responses to drought in a Mediterranean-type shrubland in South Africa. New Phytologist.

White J.W., Cook E.R. \& Lawrence J.R. 1985. The DH ratios of sap in trees: Implications for water sources and tree ring DH ratios. Geochimica et Cosmochimica Acta 49: 237-246. 


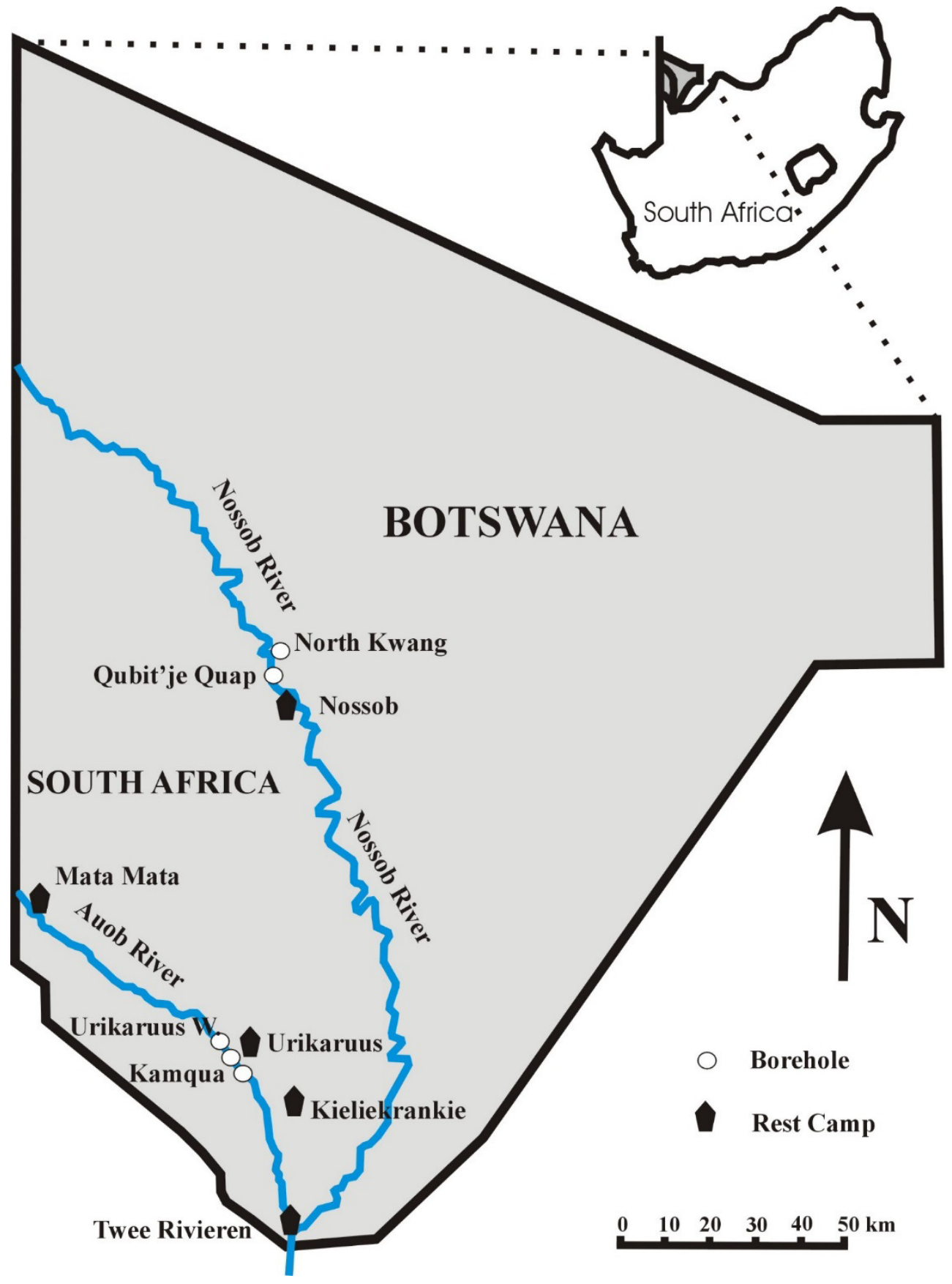

453 Figure 1. Map of the Kgalagadi Transfrontier Park showing the location of the four boreholes at which both water and twig samples were collected. The borehole for the Nossob Rest Camp is 455 between the North Kwang and Qubit'je Quap boreholes with a pipeline down to Nossob. 

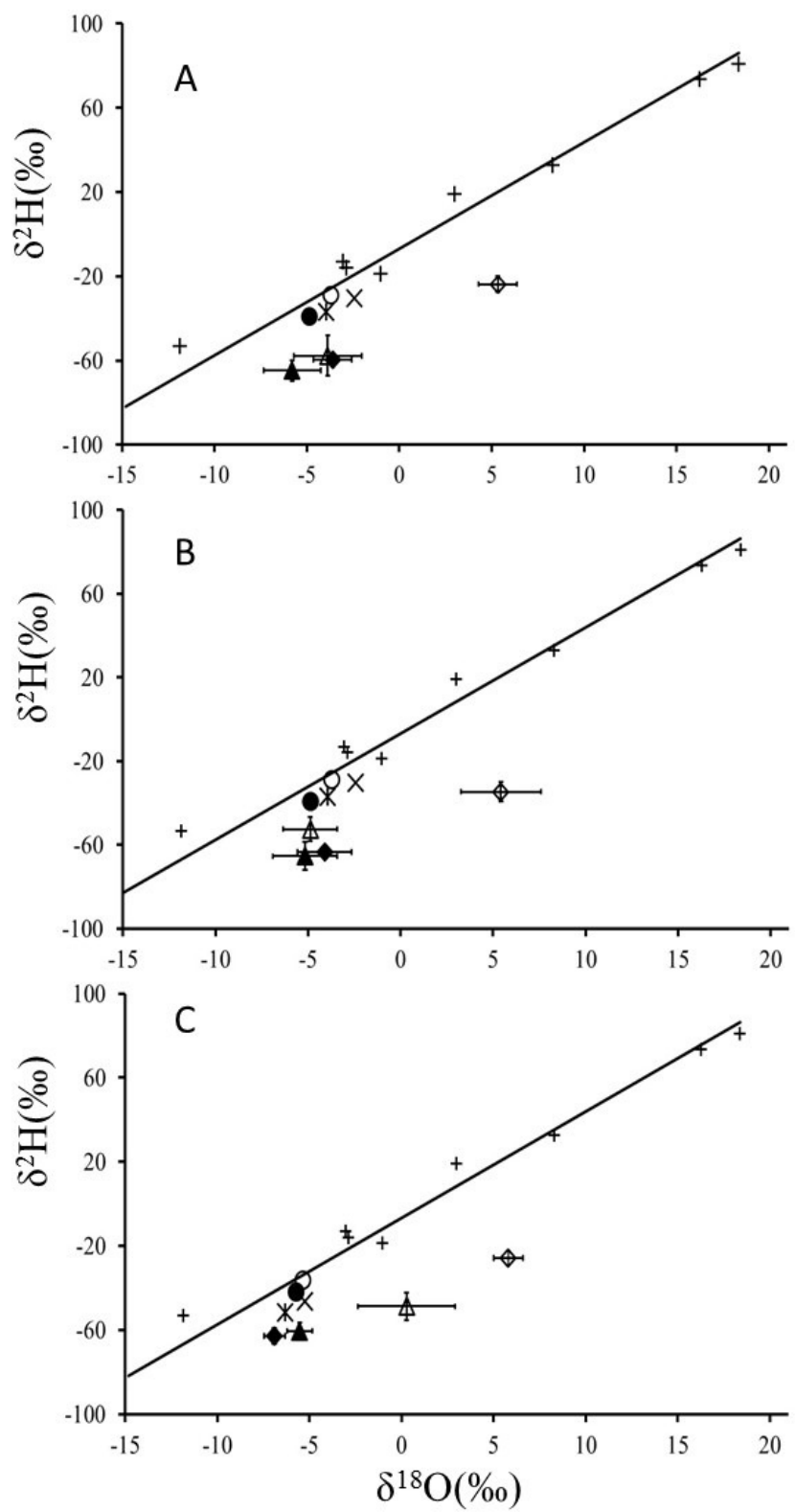

$\begin{array}{lll}\Delta \text { Trees Upstr Wet } & \Delta \text { Trees Upstr Dry } & \bullet \text { Trees Dwnstr Wet } \\ \diamond \text { Trees Dwnstr Dry } & \bullet \text { BH Upstr Wet } & \text { o BH Upstr Dry } \\ \text { *BH Dwnstr Wet } & \text { ×BH Dwnstr Dry } & \end{array}$

458 Figure 2. Mean $\delta^{18} \mathrm{O}$ and $\delta^{2} \mathrm{H}$ values ( $\pm 1 \mathrm{SE}$ ) for xylem water of (A) Auob River, Acacia haematoxylon (B) Auob River, Acacia erioloba and (C) Nossob River, Acacia erioloba for two

460 seasons (wet and dry). Values are plotted relative to the local meteoric water line ( $\mathrm{y}=5.06 \mathrm{x}-$

461 6.75) with rain $(+)$ and mean values for borehole water $(\mathrm{BH})$ included 
463
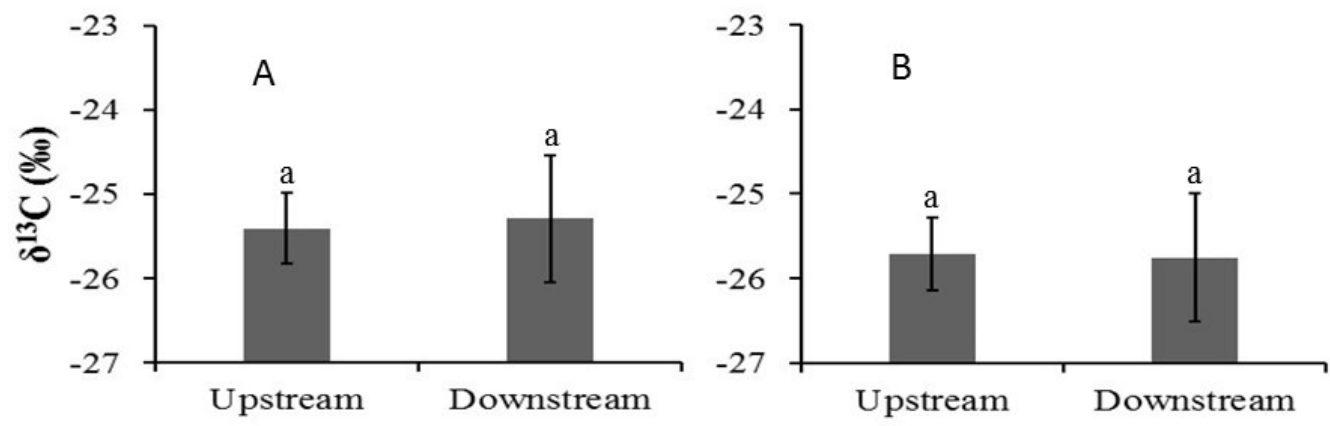

464

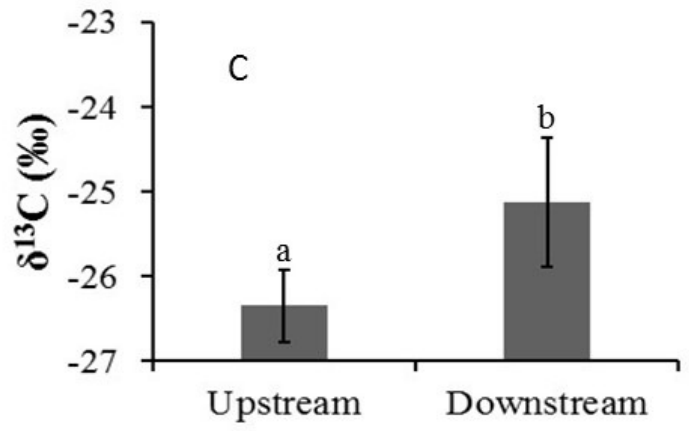

465

466

467 Figure 3. Mean leaf $\delta^{13} \mathrm{C}$ values ( $\pm 1 \mathrm{SE}$ ) for (A) Auob River Acacia haematoxylon, (B) Auob

468 River Acacia erioloba and (C) Nossob River Acacia erioloba. Different letters indicate

469 significant differences at $\mathrm{p}<0.05$ (Wilcoxon Rank Sum Test, unpaired) between upstream and 470 downstream.

471 
472

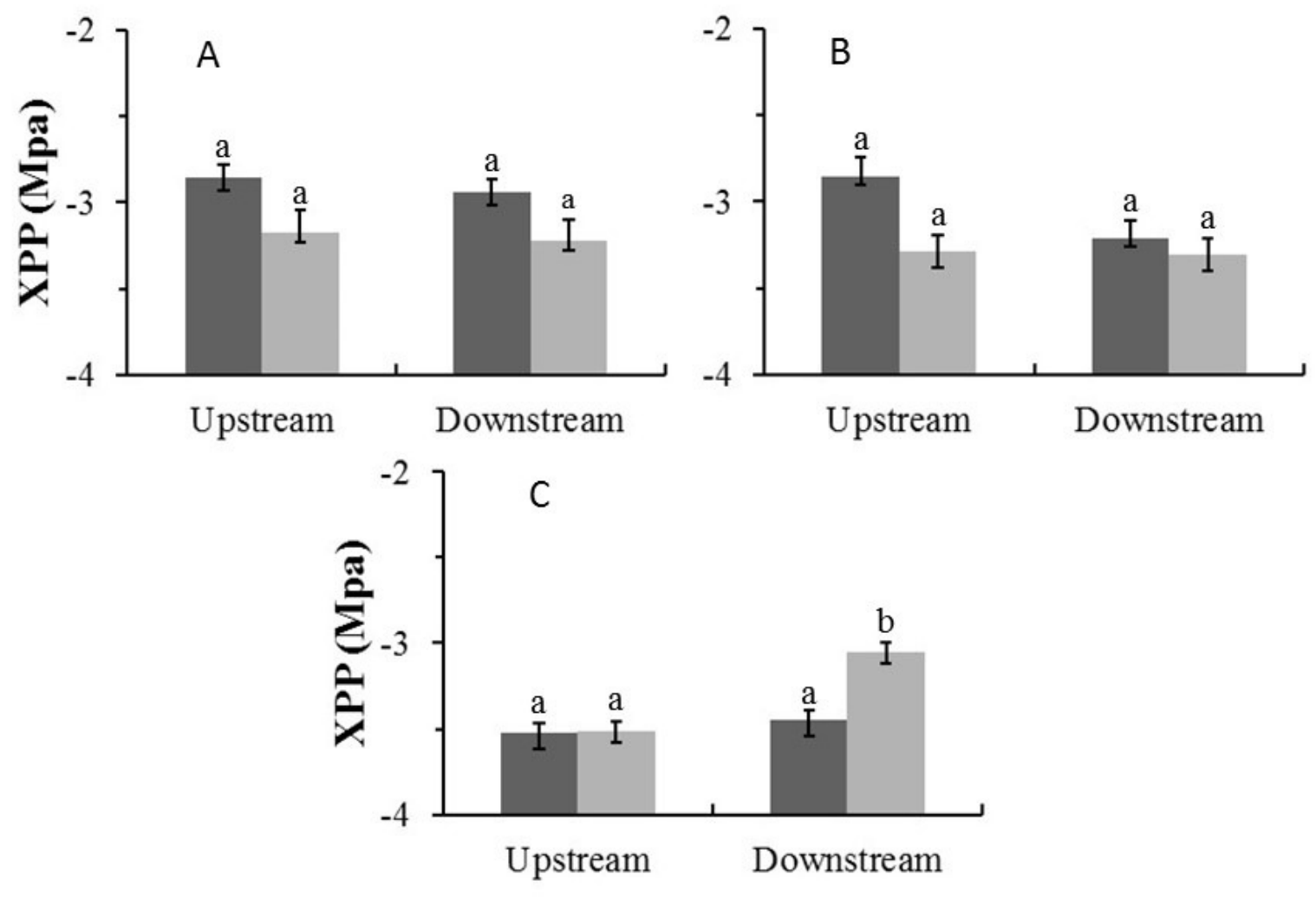

474

475

476 Figure 4. Mean midday xylem pressure potentials ( $\pm 1 \mathrm{SE}$ ) for both wet (dark) and dry (light)

477 seasons for (A) Auob River Acacia haematoxylon, (B) Auob River Acacia erioloba and (C)

478 Nossob River Acacia erioloba. Different letters denote significant differences at $\mathrm{p}<0.05$ (linear

479 mixed effects model, Simultaneous tests for generalised linear hypotheses) between upstream

480 and downstream trees within and between seasons.

481 
482

483
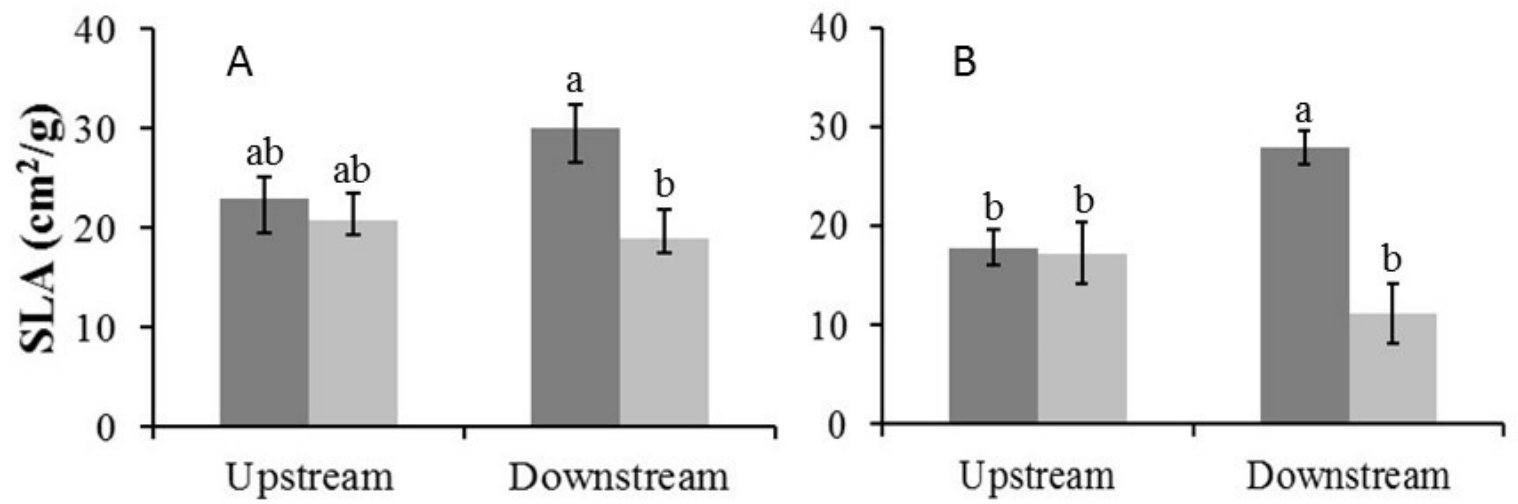

484

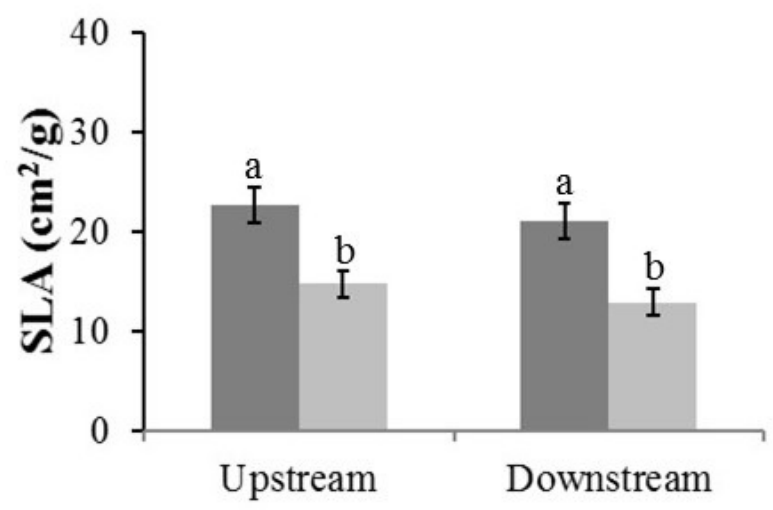

485

486 Figure 5. Mean specific leaf area $( \pm 1 \mathrm{SE})$ for both wet (dark) and dry (light) seasons for (A) 487 Auob River Acacia haematoxylon, (B) Auob River Acacia erioloba and (C) Nossob River 488 Acacia erioloba. Different letters denote significant differences at $\mathrm{p}<0.05$ (ANOVA, Tukey 489 HSD) between upstream and downstream within and between seasons.

490

491 
492

493
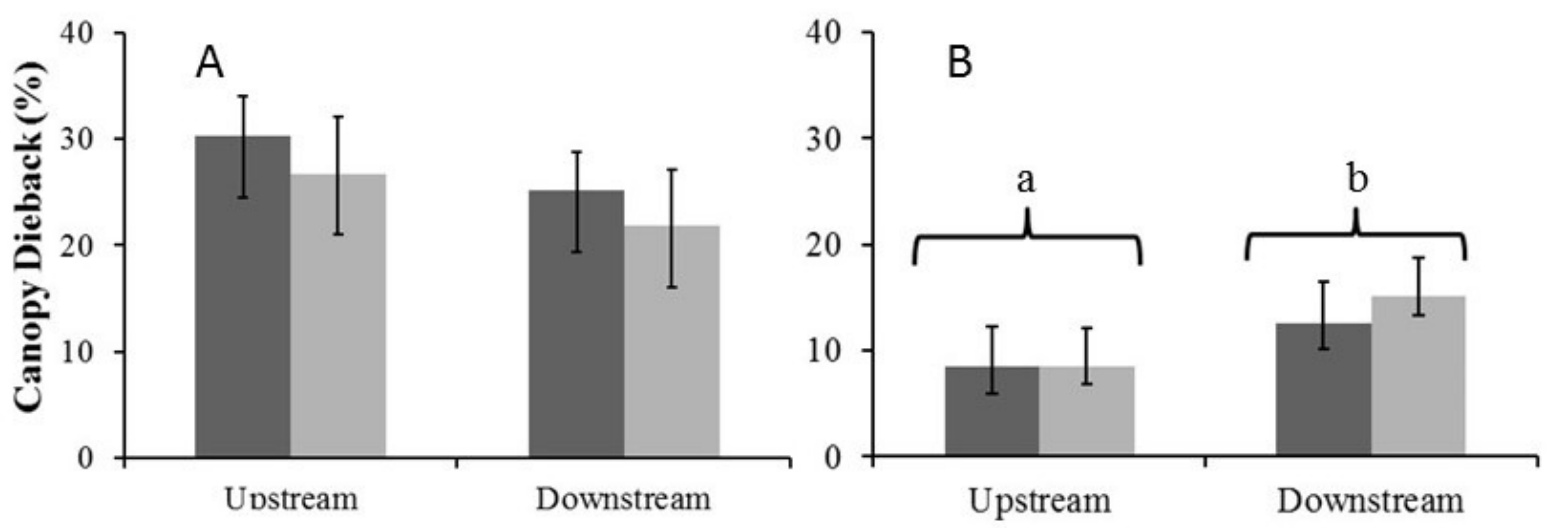

494

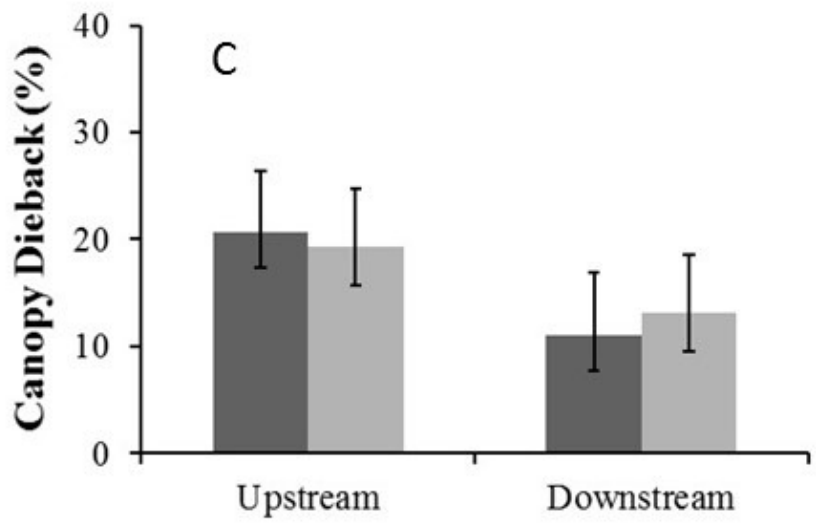

495

496 Figure 6. Mean percentage canopy dieback ( $\pm 1 \mathrm{SE})$ for both wet (dark) and dry (light) seasons 497 for (A) Auob River Acacia haematoxylon, (B) Auob River Acacia erioloba and (C) Nossob 498 River Acacia erioloba. Different letters indicate significant differences at $\mathrm{p}<0.05$ (Kruskal499 Wallis Rank Sum test followed by a Pairwise Wilcoxon with Bonferroni correction) between 500 upstream and downstream. 